\title{
Anesthesia and Rheumatoid Arthritis
}

\author{
Eneida Maria Vieira ${ }^{1}$, Stuart Goodman ${ }^{2}$, Pedro Paulo Tanaka ${ }^{3}$
}

Summary: Vieira EM, Goodman S, Tanaka PP - Anesthesia and Rheumatoid Arthritis.

Background and objectives: Rheumatoid arthritis (RA) is a chronic inflammatory disease of unknown etiology. It is known that RA patients have a reduced life expectancy when compared with the general population. Rheumatic diseases are numerous and occur with high variability; some of them develop very rapidly while others occur chronically provoking disability throughout life. Anesthetic risks in osteoarticular disorders involve not only the mechanical deformations caused by the disease, but also the cardiovascular, respiratory, renal, and digestive systems.

Contents: The purpose of this review was to stress the importance of stages in disease process that may affect anesthesia control before, during, and after surgery, highlighting the authors' experience in a retrospective review of patients with juvenile rheumatoid arthritis (JRA) undergoing placement of orthopedic prosthesis with emphasis on intubation techniques.

Conclusions: Rheumatoid arthritis patients can present a number of complex problems for the anesthesiologist. This requires careful preoperative evaluation; anesthesia requires experience with the technique; and postoperative care should be judiciously chosen to meet the specific needs of the patient. The procedure requires effective communication among surgeon, rheumatologist and anesthesiologist so each member of the multidisciplinary team can contribute with his/her expertise in order to better benefit the patient.

Keywords: Arthritis, Rheumatoid; Arthritis, Juvenile Rheumatoid; Anesthesia; Perioperative Care. Intubation, Intratracheal.

\section{INTRODUCTION}

Rheumatoid arthritis (RA) is a chronic inflammatory disease of unknown etiology. It is known that RA patients have a reduced life expectancy when compared with the general population. Rheumatic disorders are numerous and occur with high variability; some are developed very rapidly, others chronically, causing disability throughout ${ }^{1}$.

Anesthetic risks in osteoarticular disorders involve, besides mechanical deformations from the disease, the cardiovascular, respiratory, renal, and digestive systems.

The objective of this review is to highlight the importance of the disease stages, which can influence anesthesia control before, during, and after surgery, emphasizing the authors' experience in a retrospective assessment of cases of juvenile rheumatoid arthritis (JRA) patients undergoing orthopedic prosthesis, with emphasis on intubation techniques.

Received from Faculdade de Medicina de São José do Rio Preto, São Paulo, Brazil.

1. MD, PhD; Professor of Anesthesiology of Faculdade de Medicina de São José do Rio Preto

2. MD. PhD; Professor, Department of Orthopedics Stanford School of Medicine

3. MD, PhD; Clinical Associate Professor Department of Anesthesia Stanford School of Medicine

Submitted on August 16, 2010.

Approved on December 7, 2010.

Correspondence to:

Dra. Eneida Maria Vieira - ATV

Rua Cel. Spínola Castro, 4.568/52

Jardim Imperial

15015500 - São José do Rio Preto, SP, Brazil

E-mail: eneidamv@terra.com.br

\section{PRE-ANESTHETIC ASSESSMENT}

The main goal of the pre-anesthetic assessment in patients with rheumatoid arthritis is to determine the disease extension to minimize anesthetic and surgical risks. One should be aware of both the consequences of articular and systemic disease and the adverse effects of concurrent drug therapy that may interfere with anesthesia ${ }^{1,2}$.

\section{RISKS AND DIFFICULTIES SECONDARY TO ARTICULAR DAMAGE}

Rheumatoid arthritis is characterized by destruction of synovial joints, affecting mainly the small joints - the temporomandibular joint and spine joints are of particular interest to anesthesiologists. Synovial tissue affected by rheumatoid arthritis shows variations in different patients and several affected sites. Proliferation and hypertrophy of synovial cells form a layer that destroys articular cartilage, and it can cause ankylosis of the articular space with fibrosis and calcification ${ }^{2,3}$.

These articular changes have an impact on management of anesthesia:

- The presence of deformities may affect patient positioning during surgery, hindering access for regional anesthesia or venous cannulation.

- The difficulty in positioning the patient on the operating table can result in regions of the body without adequate support, requiring additional support during anesthesia. 
- Head and neck involvement in rheumatoid arthritis can result in difficult airways due to the complexity of executing the necessary maneuvers for tracheal intubation. Therefore, it is essential to try to evaluate the extension of cervical spine, temporomandibular joint, and cricoarytenoid joint involvement before anesthesia ${ }^{2}$.

\section{CERVICAL SPINE}

Radiologic studies performed with rheumatoid arthritis patients suggest that more than $80 \%$ have cervical spine involvement and, of these, over $30 \%$ may have instability with symptoms of pain related to the affected spinal segment. Anterior axial subluxation can be diagnosed by X-ray of the cervical spine. The diameter of the spinal cord canal is wider at this level, thus contributing less with neurological compression than with subaxial subluxation. In cervical spine subluxation, extension exacerbates the process, while flexion reduces it ${ }^{4}$. One should be careful to limit movements of cervical spine extension and flexion during anesthesia, which might result in difficult, if not impossible, conventional direct laryngoscopy ${ }^{2,5-7}$.

\section{TEMPOROMADIBULAR JOINT}

Temporomandibular dysfunction is frequently associated with cervical fixation, and it shows unilateral or bilateral arthritis, producing limitations in mouth opening. On upper and lower articular surfaces, fibrosis leading to ankylosis may be seen. These changes are more common in juvenile rheumatoid arthritis (JRA), frequently associated with hypoplastic mandible ${ }^{6}$. The incidence of upper airways obstruction in supine position is high in patients with temporomandibular arthritis ${ }^{8}$.

\section{CRICOARYTENOID DYSFUNCTION}

Laryngeal involvement can be seen in more than $75 \%$ of rheumatoid arthritis patients ${ }^{3}$. Symptoms are rarely evident, but fixation of the cricoarytenoid joint can present itself as a foreign body sensation in the oropharynx, dysphagia, dyspnea, hoarseness, stridor, and airways obstruction 1,3,9.

Laryngoscopy can reveal a reduction in the movement of cricoarytenoid joint and vocal cords during inspiration. Postoperative vigilance is necessary with adequate monitors and material to detect possible signs of airways obstruction after removal of orotracheal tube.

\section{SYSTEMIC DISEASES OF INTEREST TO ANESTHESIOLOGISTS}

Cardiovascular disease has been the greatest cause of RA patients mortality, being responsible for $50 \%$ of all deaths ${ }^{10,11}$. Several manifestations have been described in different studies; however, the most common include: pulmonary nodules, pleuritis, pericarditis, major cutaneous vasculitis, peripheral neuropathies, and ophthalmologic manifestations.
Pulmonary manifestations of RA are more common in male than in female, and pleural disease affects between $3 \%$ and $12.5 \%$ of patients, Pleural exudate is usually small and frequently asymptomatic ${ }^{2}$. Restrictive disorders cause secondary limitation of chest wall movements. A study on pulmonary wall compliance in RA patients and absence of lung disease suggests that the rigidity of the ribs can contribute to reduce lung volume and ventilatory efficiency ${ }^{12}$. When associated with pulmonary fibrosis, these changes cause a symmetrical reduction in forced vital capacity and forced expiratory volume. Reduction in gas exchange and exercise-induced hypoxemia are commonly seen in patients with progressive lung injury ${ }^{1,2}$.

An increased incidence of airways obstruction has been observed in RA patients. Colins et al. ${ }^{13}$ found a mean peak expiratory volume reduced in more than $50 \%$ of patients most of these patients were smokers. On the other hand, other authors ${ }^{14}$ have estimated that airflow obstruction affects $38 \%$ of rheumatoid arthritis patients.

Subclinical renal dysfunction is commonly seen in rheumatoid arthritis patients. Boers et al. ${ }^{15}$ evaluated 35 patients and demonstrated that $11 \%$ had proteinuria, $10 \%$ had deficient urinary concentration, and $8 \%$ had reduced glomerular filtration. A study that evaluated the renal excretion of $\mathrm{N}$-acetyl-beta-D-glucosaminidase, a sensitive marker of renal injury, suggests that, in the absence of nephrotoxic medications, more than $40 \%$ of RA patients have a renal function deficiency ${ }^{16}$. Significant renal disease is more common as a consequence of the toxic effects of therapy.

\section{THERAPY}

Rheumatoid arthritis treatment can be divided into two groups: drugs that improve symptoms and those used to modify the disease mechanism. The drug groups are composed of steroidal and non-steroidal anti-inflammatory agents, and can later include several agents, such as antimalarials, sulfasalazine, penicillin, azathioprine, methotrexate, and cyclosporine A. The anesthesiologist should be attentive to the adverse effects of these drugs, which can influence anesthetic technique ${ }^{17}$.

The characteristic effects of Cushing's syndrome, secondary to the use of corticosteroids, are well known. Normal cortical response during surgery can be simulated by intravenous administration of hydrocortisone $100 \mathrm{mg}$ at the time of anesthetic induction ${ }^{18}$.

\section{PREOPERATIVE INVESTIGATION}

It will depend on the nature and degree of the involved organ impairment. Table I shows guidelines for investigation.

\section{CARE DURING ANESTHESIA}

\section{Techniques}

The choice of technique will depend on the general condition of the patient and type of surgery ${ }^{1,2}$. Whenever possible, surgery should be performed under regional anesthesia. The 
Table I - Pre-anesthetic Assessment

\begin{tabular}{|c|c|}
\hline EXAMINATION & JUSTIFICATION \\
\hline \multicolumn{2}{|l|}{ In all cases } \\
\hline \multirow[t]{2}{*}{ Complete blood count } & Anemia by Gl losses \\
\hline & Drug-induce dyscrasia \\
\hline Electrolytes and BUN & Renal involvement, drug toxicity \\
\hline Electrocardiogram & $\begin{array}{l}\text { Arrhythmias, conduction defect, } \\
\text { ischemia, chamber hypertrophy } \\
\text { secondary to valvular disease }\end{array}$ \\
\hline Chest X-ray & $\begin{array}{l}\text { Pulmonary fibrosis, } \\
\text { kyphoscoliosis, heart area }\end{array}$ \\
\hline Cervical spine X-ray & $\begin{array}{l}\text { Flexion deformities, vertical or } \\
\text { horizontal translocation. Instability }\end{array}$ \\
\hline \multicolumn{2}{|l|}{ Whenever indicated } \\
\hline \multirow[t]{2}{*}{ Pulmonary function tests } & $\begin{array}{l}\text { Involvement of the pulmonary } \\
\text { wall or restrictive disease }\end{array}$ \\
\hline & Arterial blood gases \\
\hline Liver function tests & Low albumin - drug toxicity \\
\hline \multirow[t]{2}{*}{ Direct laryngoscopy } & Symptoms of joint involvement \\
\hline & Cricoarytenoid \\
\hline Echocardiography & $\begin{array}{l}\text { Valvular heart disease } \\
\text { Pericarditis }\end{array}$ \\
\hline
\end{tabular}

Gl: gastrointestinal; BUN: Blood urea nitrogen.

advantages of local anesthesia include avoidance of airways manipulation due to ventilatory changes related to general anesthesia. Catheter techniques may be used for effective postoperative analgesia. However, the formation of ankylosis and osteophytes can make spinal or epidural anesthesia difficult. These techniques may be contraindicated in the presence of thrombocytopenia or in patients on anticoagulation.

General anesthesia has the advantage of providing greater cardiovascular and respiratory control; in addition, it can minimize the fact that the patient is in an uncomfortable position, and there is no limit for the duration of anesthesia-surgery ${ }^{1,2}$. Before anesthetic induction, the head and cervical spine should be fixed in a comfortable position with a wedge to limit more intense cervical movement. Laryngeal mask helps maintain the airways patent for long periods and it can be used as an instrument in tracheal intubation ${ }^{19}$.

The development of the fiberoptic bronchoscope has dramatically changed the cervical spine care during anesthesia, when tracheal intubation is deemed necessary ${ }^{20}$. The technique facilitates neck immobilization during pre-induction without compromising the success. The fiberoptic bronchoscope can be used through the nose or oropharynx, with patients awake, or breathing spontaneously under general anesthesia. However, its use requires training.

In the authors' experience, through review of medical records, this approach was used in 21 out of 50 patients with JRA undergoing orthopedic surgeries as the technique of choice for airway management. This group of patients had a mean age of 31 years at the time of surgery. Anatomical limitations already described, such as cervical immobility, ankylosis of the temporomandibular joints and mandibular hypoplasia, associated or not with a history of difficult intubation, were the determining factors for fiberoptic bronchoscopy use. Laryngeal mask was another resource used in patients whose mouth opening allowed it, usually openings greater than $2 \mathrm{~cm}$. The laryngeal mask has double purpose: first, it allows surgery to be performed using only the mask; and second, as a passage for fiberoptic bronchoscope while, at the same time, maintaining the airway viability. In JRA patients who were classified as grade II according to the Mallampati classification, with good mouth opening, a direct laryngoscopy was the method of choice for tracheal intubation. Macintosh number 2 blade was used more often with the aid of a Bougie in McCormick III or McCormick IV presentation.

\section{PHARMACOLOGY}

After the technique is chosen, it is important to assess which anesthetic drugs can have its pharmacology modified as the result of changes in plasma protein concentration or renal dysfunction in rheumatoid arthritis patients. Reduction in serum protein levels and increased in alpha-1-glycoprotein (AAG) may change the free fraction of drugs. Net results of the effects depend on the original protein binding of drugs ${ }^{21,22}$. For example, the effects of diazepam, which show high albumin binding (98\%), can be exaggerated in the presence of hypoalbuminemia. On the other hand, drugs with moderate binding (for example, muscle relaxants) may only increase the free fraction of a small portion. Drugs with high AAG affinity (verapamil, metoclopramide, propranolol) may have a decreased free fraction and, as a result, a reduction in its therapeutic effects. This can be an advantage when considering local anesthetics.

Studies that evaluate pharmacokinetics in rheumatoid arthritis are lacking, but it is known that the dose and frequency of drug administration should be carefully titrated to avoid toxic effects.

\section{POSTOPERATIVE CARE}

In the postoperative period the objective is to provide effective analgesia, minimize the risk of respiratory failure, and abbreviate the immobilization period.

Rheumatoid arthritis patients are more sensitive to drugs, and are more predispose to develop respiratory depression ${ }^{23}$. If considered appropriate, analgesia with opioids should be carefully titrated. The use of controlled analgesia systems can be difficult in the presence of arthritis involving the hands. The association of obstructive apnea with temporomandibular joint destruction, mandibular hypoplasia, and other type of non-complicated rheumatoid arthritis may increase the susceptibility of patients to the effects of opioid-induced respiratory depression ${ }^{24-26}$. 
The most frequent technique of anesthesia for lower limbs surgical procedures is spinal anesthesia with isolated local agent or associated with opioids to provide effective postoperative anesthesia. Continuous peripheral nerve or lumbar plexus block for the lower limb surgeries are also used as an alternative to continuous analgesia and they are a more logical approach for postoperative pain care.

Respiratory failure can be precipitated by a large number of overlapping causes of preexisting problems. A restrictive disorder predisposes patients to hypoventilation, atelectasis, pulmonary infection, and hypoxemia, especially when the diaphragm is fixed due to pain, obesity, or bandages. Immunosuppressive agents can lead more susceptible patients to develop pulmonary infections.

Fixation of the spine can leave the patient bedridden, making thoracic physiotherapy more difficult. Passive exercises can reduce worsening or development of contractures and should be initiated as soon as possible.

Whenever appropriate, protective corticosteroids should be continued. In high risk patients, prophylactic methods for peptic ulcers or ulceration should be used.
Renal function should be carefully monitored in the postoperative period in situations of prior renal impairment superimposed on drug nephrotoxicty and hypovolemia, reducing renal blood flow.

\section{CONCLUSION}

Rheumatoid arthritis patients can present a large number of complex problems for the anesthesiologist. This requires careful preoperative evaluation; anesthesia requires experience with the technique; and postoperative care should be carefully chosen to meet specific patient needs. The procedure demands effective communication between surgeon, rheumatologist, and anesthesiologist so each member of the multidisciplinary team can contribute with his/her expertise, in order to better benefit the patient. 


\section{REFERÊNCIAS / REFERENCES}

01. Lisowska B, Rutkowska-Sak L, Maldyk P et al. - Anaesthesiological problems in patients with rheumatoid arthritis undergoing orthopaedic surgeries. Clin Rheumatol, 2008;27:553-556.

02. Skues MA, Welchew EA - Anaesthesia and rheumatoid arthritis. Anaesthesia, 1993;48;989-997.

03. Charlin B, Brazeau-Lamontagne L, Levesque RY et al. - Cricoarytenoiditis in rheumatoid arthritis comparison of fibrolaryngoscopic and high resolution computerized tomographic findings. J Otolaryngol, 1985;14:381-386

04. Tokunaga $\mathrm{D}$, Hase $\mathrm{H}$, Mikami $\mathrm{Y}$, et al. - Atlantoaxial subluxation in different intraoperative head positions in patients with rheumatoid arthritis. Anesthesiology, 2006;104:675-679.

05. Gurcay E, Eksioglu E, Yuser $S$ et al. - Articular damage in adults with juvenile idiopathic arthritis. Rheumatol Int, 2009;29:635-640.

06. Ansell BM. Classification and Nomenclature, em: Woo P, White PH, Ansell BM - Paediatric Rheumatology Update. Oxford, Oxford University Press, 1990;3-5.

07. Winkler $M$; Marker $E$, Hertz $M$ - The peri-operative management of major orthopaedic procedures. Anaesthesia, 1998;53(suppl):37-41.

08. Reginster JY, Damas $\mathrm{P}$, Franchimont $\mathrm{P}$ - Anaesthetic risks in osteoarticular disorders. Clin Rheumatol, 1985;4:30-38.

09. Leicht MJ, Harrington TM, Davis DE - Cricoarytenoid arthritis: a cause of laryngeal obstruction. Ann Emerg Med, 1987;16:885-888.

10. Galvin EM, O'Donnell D, Leonard IE - Rheumatoid arthritis: a significant but often underestimated risk factor for perioperative cardiac morbidity. Anesthesiology, 2005;103:910-911.

11. Goodson N - Coronary artery disease and rheumatoid arthritis. Curr Opin Rheumatol, 2002;14:115-120.

12. Begin R, Radoux V, Cantin A et al. - Stiffness of the rib cage in a subset of rheumatoid patients. Lung, 1988;166:141-148.

13. Collins RL, Turner RA, Johnson AM et al. - Obstructive pulmonary disease in rheumatoid arthritis. Arthritis Rheum, 1976;19:623-628.

14. Geddes DM, Webley M, Emerson PA - Airways obstruction in rheumatoid arthritis. Ann Rheum Dis, 1979;38:222-225.

15. Boers $M$, Dijkmans BA, Breedveld FC et al. - Subclinical renal dysfunction in rheumatoid arthritis. Arthritis Rheum, 1990;33:95-101.

16. Dieppe PA, Doyle DV, Burry HC et al. - Renal disease in rheumatoid arthritis. Br Med J, 1976;1:611-612.

17. Plumpton FS, Besser GM, Cole PV - Corticosteroid treatment and surgery. The management of steroid cover. Anaesthesia, 1969;24:1218. 
18. Kehlet $\mathrm{H}$ - A rational approach to dosage and preparation of parenteral glucocorticoid substitution therapy during surgical procedures. A short review. Acta Anaesthesiol Scand, 1975;19:260-264.

19. Keenan MA, Stiles CM, Kaufman RL - Acquired laryngeal deviation associated with cervical spine disease in erosive polyarticular arthritis. Use of the fiberoptic bronchoscope in rheumatoid disease. Anesthesiology, 1983;58:441-449.

20. Vaughan RS - Training in fibreoptic laryngoscopy. $\mathrm{Br} J$ Anaesth, 1991;66:538-540.

21. Wood M - Plasma drug binding: implications for anesthesiologists. Anesth Analg, 1986;65;786-804.

22. Pihlajamaki KK; Lindberg RLP - Bupivacaine with and without adrenaline in interscalene brachial plexus blockade. Studies in patients with rheumatoid arthritis. Br J Anaesth, 1987;59:1420-1424.

23. Davies SF, Iber C - Obstructive sleep apnea associated with adultacquired micrognathia from rheumatoid arthritis. Am Rev Resp Dis, 1983;127:245-247.

24. Lavie $\mathrm{P}, \mathrm{Nahir} \mathrm{M}$, Lorber $\mathrm{M}$ et al. - Nonsteroidal antiinflammatory drug therapy in rheumatoid arthritis patients. Lack of association between clinical improvement and effects on sleep. Arthritis Rheum, 1991;34:655-659.

25. Gordon DA, Stein JL, Broder I - The extra-articular features of rheumatoid arthritis. A systematic analysis of 127 cases. Am J Med, 1973; 54:445-452.

26. Gardner DL, Holmes F - Anaesthetic and postoperative hazards in rheumatoid arthritis. Br J Anaesth, 1961;33:258-264.

Resumen: Vieira EM, Goodman S, Tanaka PP - Anestesia y Artritis Reumatoide.

Justificativa y objetivos: La artritis reumatoide (AR), es una enfermedad inflamatoria crónica y de etiología desconocida. Los pacientes con $A R$ son reconocidos como personas que tienen una reducción en la expectativa de vida, en comparación con la población en general.
Las enfermedades reumáticas son numerosas y ocurren con una alta variabilidad; algunas son desarrolladas rápidamente; otras, crónicamente, provocando incapacidades durante toda la vida. Los riesgos anestésicos, en los desórdenes osteoarticulares, involucran además de las deformidades mecánicas causadas por la enfermedad, los sistemas cardiovascular, respiratorio, renal y digestivo.

Contenido: La propuesta de la presente revisión fue destacar la importancia de las fases de la enfermedad en proceso, que pueden influir en el control de la anestesia antes, durante y después de la cirugía, destacando la experiencia de los autores en una evaluación retrospectiva de los casos de pacientes portadores de artritis reumatoide juvenil (ARJ), sometidos a prótesis ortopédicas, con énfasis en las técnicas de intubación.

Conclusiones: Los pacientes con artritis reumatoide pueden presentar un buen número de problemas complejos para el anestesiólogo. Eso requiere una cuidadosa evaluación preoperatoria; la anestesia necesita tener ya una experiencia con la técnica y el cuidado postoperatorio debe ser juiciosamente elegido para atender a la necesidad específica del paciente. El procedimiento exige una efectiva comunicación entre el cirujano, el reumatólogo y el anestesiólogo, para que cada miembro del grupo multidisciplinario contribuya con su experiencia, y así lograr un mejor beneficio para el paciente.

Descriptores: ANESTESIA; CIRUGÍA, Cuidado preoperatorio; COMPLICACIONES, Intubación traqueal; ENFERMEDADES, Reumatologicas: artritis reumatoide, artritis reumatoide juvenil. 